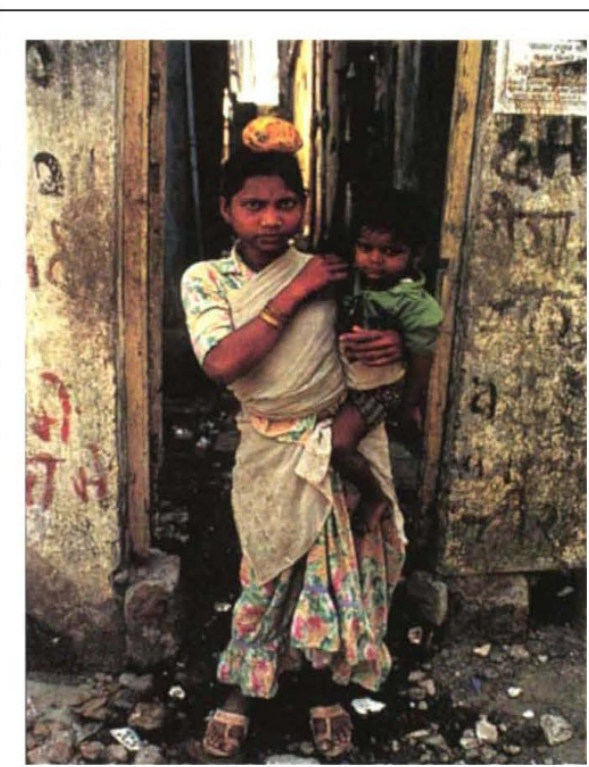

Poverty trap: will gene therapy help?

gene therapy studies. This amounts to about 2 per cent of the total annual budget for medical research.

Critics fear that existing health research will suffer if the best molecular biologists switch to gene therapy, which they say is fashionable but has questionable benefits. "It is absolutely ridiculous for India to jump onto the gene therapy bandwagon when people are still dying due to infectious diseases and malnutrition," says Dipankar Banerjee, an emeritus professor of community medicine at the Jawaharlal Nehru University in New Delhi.

However, others disagree. Govindarajan Padmanabhan, director of the Indian Institute of Science in Bangalore, says some aspects of gene therapy are highly relevant to India. For example, he says, techniques for the direct delivery of DNA to cells have led to the development of a DNA vaccine against rinderpest by the institute which is currently being tested in cattle, with results due later this month. The vaccine does not need a cold chain and is cheap. Such direct DNA immunization "has the potential to treat not only genetic disorders but also communicable diseases", says Padmanabhan.

Ishwar Verma, who runs a genetic counselling centre at a city hospital in New Delhi, says that 25 children with thalassemia are born in India daily, as well as ten with Duchenne muscular dystrophy and eight with haemophilia. As infant death rates fall overall, the numbers of surviving children who need treatment for such disorders may in- crease, says Verma. "If we fail to develop our own gene therapy technologies now, we will end up importing them or sending our patients abroad for treatment."

As the commonest of the gene disorders, thalassemia tops the biotechnology department's list of candidates for gene therapy. But in the absence of a viable proposal, priority has been given instead to a gene targeting technique developed by a team led by Rita Mulherkar of the Cancer Research Institute in Bombay for the treatment of tobacco-related oral cancer, the leading cancer among Indian
males.The therapy delivers a gene that makes cancer cells selectively vulnerable to the drug ganciclovir. "We are ready to begin human trials," says Mulherkar. Other projects being funded by the DBT include an experimental system to deliver DNA direct to liver cells, based on a modified Sendai virus. So far this approach, led by Debi Sarkar at Delhi University, has been tested only in mice, but the DBT hopes it could one day be used to develop treatments for diabetes and haemophilia.

K.S.JAYARAMAN New Delhi

\title{
Bold action on health marks Labour's first month in office
}

Britain's new Labour government moved quickly to fulfil a pre-election pledge to make health a government-wide responsibility rather than one for the Department of Health alone. The Prime Minister, Tony Blair, last month appointed a minister for public health to oversee the health-related aspects of activities in other departments, such as transport, agriculture and the environment. The minister, Tessa Jowell, will report to the new Secretary of State for Health, Frank Dobson.

The government also confirmed its commitment to end the so-called "internal market" introduced into the National Health Service (NHS) by the Conservatives. And, in direct response to widespread criticism of the previous government's handling of food safety issues, such as last year's BSE scare, it will establish an independent food standards agency.

The moves were immediately welcomed by the British Medical Association, the professional body which represents doctors. The BMA particularly endorsed the adoption of a governmentwide strategy, which ministers say will include measures such as a ban on tobacco advertising. "We have been asking for this for a very long time," said Sandy Macara, the association's president. Macara also applauded the decision to end the internal market in the NHS. While the market was intended to establish a clear separation between the pur- chasers and providers of health care, it became an accounting nightmare as every medical transaction had to be costed. "We need a system which is cooperative rather than competitive," said Macara.

But the government has yet to indicate how it will meet its campaign commitment to achieve a real increase in spending on the NHS. Macara and others are sceptical that this can be achieved in the way the government claims - that is, with management savings made by ending the market system. There is also uncertainty about how the government will preserve the more positive aspects of the internal market, particularly the formal separation between those responsible for assessing needs and allocating resources, and those responsible for providing health care.

DAVID DiCKSON

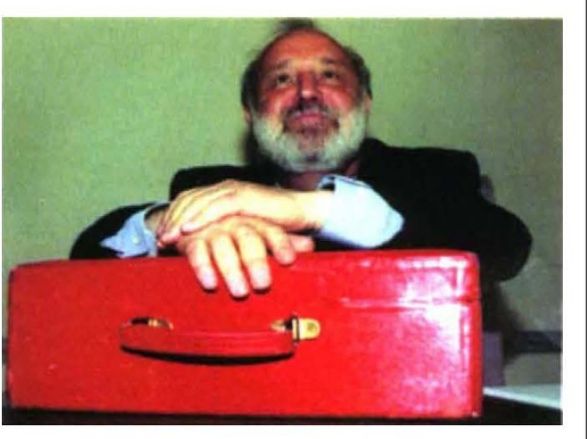

Hands-on approach: Frank Dobson 